\title{
LEAF ANATOMY OF SENNA CANA (FABACEAE) IN A SEASONALLY DRY TROPICAL FOREST ${ }^{1}$
}

\author{
LUCAS DA PENHA XAVIER ${ }^{2}$, EMILIA CRISTINA PEREIRA DE ARRUDA ${ }^{2 *}$
}

\begin{abstract}
In seasonally dry tropical forests such as the Brazilian Caatinga, factors such as soil type and luminosity are known to cause changes in foliar tissues that enable the survival of species in such places. The present study aimed to describe the leaf morphoanatomy of Senna cana and to observe the plasticity in leaf tissues receiving both direct and indirect light radiation. The study was carried out in the Catimbau National Park in Buíque, PE, Brazil. Mature leaf samples were collected from under full sunlight and full shade in three areas with soils of different colors. Histological slides were prepared for visualization of epidermal faces, internal leaf structure, and histochemical tests. Plasticity was noted in the type of trichome that covered the epidermal faces, and in the number of layers of the palisade and spongy parenchymas, even under the indirect effect of radiation. Phenolic compounds and lipids also showed plasticity. These results demonstrate that Senna cana is a species with high plasticity for the luminosity factor. Further, it was noticed that indirect light also promotes anatomical changes and should be considered in future analyses.
\end{abstract}

Keywords: Caatinga. Semi-arid. Sunlight. Trichomes. Xerophytes.

\section{MORFOANATOMIA FOLIAR DE SENNA CANA (FABACEAE) EM UMA FLORESTA TROPICAL SAZONALMENTE SECA}

Em florestas tropicais sazonalmente secas, como a Caatinga brasileira, fatores como tipo de solo e luminosidade são conhecidos por causar alterações nos tecidos foliares que possibilitam a sobrevivência de espécies nesses locais. O presente estudo teve como objetivo descrever a morfoanatomia foliar de Senna cana e observar a plasticidade em tecidos foliares que recebem radiação de luz direta e indireta. O estudo foi realizado no Parque Nacional do Catimbau em Buíque, PE, Brasil. Amostras de folhas maduras foram coletadas sob plena luz do sol e plena sombra em três áreas com solos de cores diferentes. Lâminas histológicas foram preparadas para visualização das faces epidérmicas, estrutura foliar interna e testes histoquímicos. A plasticidade foi notada no tipo de tricoma que recobriu as faces epidérmicas, e no número de camadas dos parênquimas paliçádico e esponjoso, mesmo sob efeito indireto da radiação. Compostos fenólicos e lipídios também apresentaram plasticidade. Esses resultados demonstram que Senna cana é uma espécie com alta plasticidade para o fator de luminosidade. Além disso, percebeu-se que a luz indireta também promove alterações anatômicas e deve ser considerada em análises futuras.

Palavras-chave: Caatinga. Semiárido. Luz do sol. Tricomas. Xerófitas. 


\section{INTRODUCTION}

The Brazilian seasonally dry tropical forest, known as the Caatinga, is the only phytogeographic domain of Brazil that falls entirely within the limits of the national territory (QUESADA et al., 2009; SANTOS et al., 2011). The area was approximately $844,453 \mathrm{~km}^{2}$ (IBGE, 2004), which borders the Cerrado, Amazonian, and Atlantic Forest, which favors different ecotones (QUESADA et al., 2009; SANTOS et al., 2011). Regarding climate, the Caatinga presents very extreme conditions in contrast to other Brazilian vegetation formations, with the highest insolation, temperature, and evapotranspiration as well as lower relative humidity and precipitation (LIMA et al., 2012).

Most of the Caatinga is located in the northeast portion, with a dominance of crystalline rocks that were elevated by tectonic events that occurred during the tertiary period, and that originated the inselbergsthrough erosive processes (LOPES-SILVA et al., 2019). Araújo-Filho et al. (2017) reported that Caatinga's soils are shallow and rocky outcroppings are frequent and show different colors related to its chemical and physicochemicalproperties. Similarly, according to Prado (2003), pediments covered by rocks, and rocky outcroppings called "lajedos" are typical, and latosols originating from the action of climate on the parent rock occur frequently. The geological formation process of the Caatinga resulted in varied and patchily distributed soils (SANTOS et al., 2013), which have influenced the vegetation. Latosols and nearby sandy soils can contain the same plant species with different-sized individuals (PRADO, 2003).

Schlichting (2002) found that the morphology of plants is genetically determined, but can be influenced by the environment. In xeric areas, it is common for plants to develop smaller leaves to limit transpiration and ameliorate the adverse effects of high temperatures (FAHN; CUTLER, 1992; FIGUEIREDO et al., 2015). However, they may be thickened due to the accumulation of photosynthetic tissues as well as due to storage of water in the mesophyll (BOEGER; GLUZEZAK, 2006).

One of the leading causes of stress in plant species in the Caatinga is the high level of exposure to ultraviolet-B radiation, which is capable of slowing the growth of individuals and decreasing leaf area (ZHAO et al., 2020). This damage varies according to the degree of exposure of the leaves, with leaves closer to the ground being less susceptible to the negative effects of ultraviolet-B radiation due to shading (PARISI et al., 1998). Furthermore, leaves growing in the sun are known to exhibit marked morphological differences when compared to those in the shade. In general, they are thicker and possess more layers of palisade parenchyma in relation tospongy parenchyma, which, according to Kim et al. (2005), occurs due to directional cell divisions and is not related to the increase in cell number. Therefore, it is necessary to consider exposure to light when performing studies of ecological anatomy on leaves, which are strongly influenced by such a variable.

The epidermis is the tissue in direct contact with the external environment and candevelop specialized cells to provide environmental adjustments in plants. Regarding the stomata, Fahn and Cutler (1992) consideredamphystomy as a standard feature for plants in sunny and xeric sites. A possible explanation is the improvement of the conductance of gases within the leaf, made possible by the presence of the stomata on the adaxial (upper) side of the leaves (GUERFEL et al., 2009; YOO et al., 2010; FAN et al., 2013). Under such conditions, an elaborate indument of trichomes capable of enhancing ultraviolet ray reflection and avoiding water loss through sweating (KARABOURNIOTIS et al., 2020), and a thick cuticle with the same purpose (YANG et al., 2011) are commonly exhibited.

Plant secondary metabolitesimprove plant growth and survival under different environmental stresses (ASHRAF et al., 2018). Substances such as phenolic compounds can reduce the passage of light and the deleterious effects caused by radiation (IZAGUIRRE et al., 2007). Barros and Soares (2013) considered herbivory and photo-protectionas essential functions for plants during drought. Different plant taxa can adapt to local environmental conditions, and semi-arid regions around the world exhibit high levels of species richness.

Several floristic inventory studies carried out in the Caatinga have shown that the Fabaceae family is the most representative, followed by Euphorbiaceae (ALCOFORADO-FILHO, 2003; ROCHA et al., 2004; RODAL et al., 2008; GOMES; ALVES, 2010; MACHADO et al., 2012; SANTANA et al., 2016). Fabaceae are dominant even in areas with different soils (COSTA et al., 2015) and distinct phyto-physiognomies (ARAÚJO et al, 2011), which indicates a high resistance capacity to local stresses.Senna cana (Nees\& Mart.) H.S.Irwin \& Barneby, analyzed in this study, is a native, episodic, evergreen, and a potentially medicinalspecies. Itisfound in Caatinga, Campos Rupestres, Cerrado, and rocky outcroups (MONTEIRO, 2012), andcan be an ideal model species for ecological and plasticity studies.

Although the family has been well studied, little is known about the anatomy of the group, especially for seasonally dry tropical forests. Further studies are required to describe and understand not only the tissue structure of representative taxa, but also the physiology and ecology of these species. This study aimed to characterize the foliar morphoanatomy of individuals of Senna cana (Fabaceae) present in the Caatinga, and to identify plastic anatomical variations related to the color of 
thesoil in which these plants were established as well as the degree of light incident on the leaves.

\section{MATERIALS AND METHODS}

The study was carried out in January 2017 in the Catimbau National Park, at $8^{\circ} 30^{\prime} 57^{\prime}$ S, $37^{\circ}$ 20'59" W, within the limits of the municipality of Buíque, Pernambuco, Brazil. Mature leaves were sampled from the fourth node of nine adult individuals of Senna cana. Leaf samples exposed to sunlight and shade were collected from the same individuals. The material was obtained from three sites of the park, designated as A, B1, and B2. Site A wasa rocky outcrop with grayish-colored rocks, B1 hadlight-toned sandy soil, and B2 hadthe same soil, part of which was covered with litter, making the substrate blackish (Figure 1).
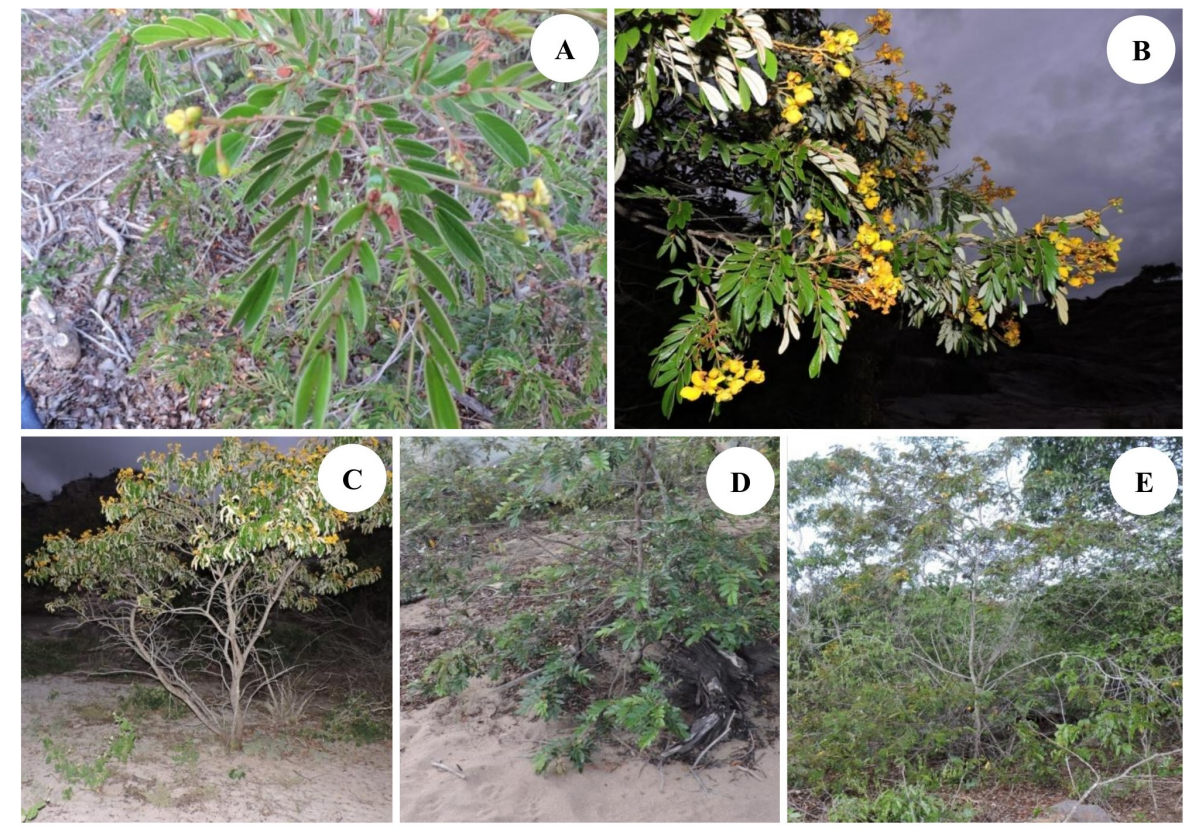

Figure 1. Senna cana in different soils of Catimbau National Park. A-B. General aspects of leaves and inflorescences. C. Individual on rocky outcrops (A). D. Individual on sandy soil (B1). E. Individual occurring on sandy soil with litter cover (C).

For each site, three specimens were sampled and stored in FAA50 for fixation and transferred to $70 \%$ ethanol after 48 hours (JOHANSEN, 1940).

In order to visualize the components of the epidermis, the epidermal dissociation technique was used, where sections of the median region of the leaves of each individual were made. The samples were then placed in Petri dishes containing commercial sodium hypochlorite (KRAUS; ARDUIN, 1997), until complete clarification, with three replicates for each material. The adaxial (upper) and abaxial (lower) surfaces were isolated from each other for analysis, stained with $1 \%$ safranin diluted in distilled water, and mounted on slides in 50\% glycerin (PURVIS et al., 1964).

The characterization of the internal structure of the leaves, was obtained through small cuttings, which were detached from the median leaf region and immersed in a gradual series of butanol-ethanol (50-100\%). Thereafter, the material was embedded in histological paraffin according to a methodology proposed by Kraus and Arduin (1997), mounted on cassettes, and taken to a LUPETEC MR09 microtome to perform the transversal sections, which ranged in thickness from 10 to $14 \mu \mathrm{m}$. The sections were stained with $1 \%$ Astra blue and 1\% safranin and mounted on Canada Balsam (GERLACH, 1984) for observation.

Two histochemical tests were performed in this study, one for the visualization of phenolic compounds and the other for the presence of lipid substances. Slides were dewaxed, and ferric chloride (JOHANSEN, 1940) and Sudam III (SASS, 1951) wereapplied for the detection of phenolic compounds and lipids, respectively. The material was mounted in $50 \%$ glycerin and sealed with nail polish.

The observations were made using an optical microscope Leica DM500 with a coupled camera. ImageJ software (Version 1.50i) was used to measure the following biometric parameters: average cell wall thickness, density of trichomes, total thickness of the mesophyll as well as that of the palisade and spongy parenchymas, cuticle thickness of each epidermal face, and length of adaxial and 
abaxial epidermal cells. In addition, the number of cell layers of the palisade and spongy parenchyma were taken into account.

For the statistical evaluation, an analysis of variance (ANOVA) for two factors was used to verify if there were differences between the three sites (A, B1, and B2) and the two light conditions (sunlight exposed and shaded). The comparisons between the adaxial and abaxial faces were made using a t-test, and normality was tested using a Shapiro-Wilk test. The adaxial cuticle thickness data were not normally distributed, therefore, nonparametric and non-normal analyses were used to compare areas with leaf type (Kruskal-Wallis) and adaxial $\times$ abaxial relation (Wilcoxon). All analyses were performed using PAST software (4.03 version).

\section{RESULTS AND DISCUSSION}

The quantitative and qualitative leaf features of the Senna cana species revealed traits adaptive to a dry environment independent of the area of
Caatinga studied, as expected. However, characters such as the type of epidermal trichomes, the number of layers of the palisade and spongy parenchymas, and the occurrence of phenolic compounds and lipids can be related to solar radiation, especially in lightcoloredsoil.

The walls of the epidermis cells of Senna cana showed straight contours with no difference in thickness in adaxial surfaces (Figure 2), contrary to the findings of Leite and Lleras (1978), who studied Pogonophora schomburgkiana Miers. They observed increased xeric characteristics on leaf extracts with the highest exposure to the sun, including thick cell walls. Others have found straight and thickened cell walls related to protection against excessive water loss and thermal insulation (GUERRA; SCREMIN-DIAS, 2018). This characteristic was detected onlyin the abaxial epidermis ofindividuals of the area B1 (sandy soil), which may be related to defenseagainstsolar radiation, reflected by soil as described by NOVAIS et al. (2018), since trichome density was reduced in the abaxial epidermis.

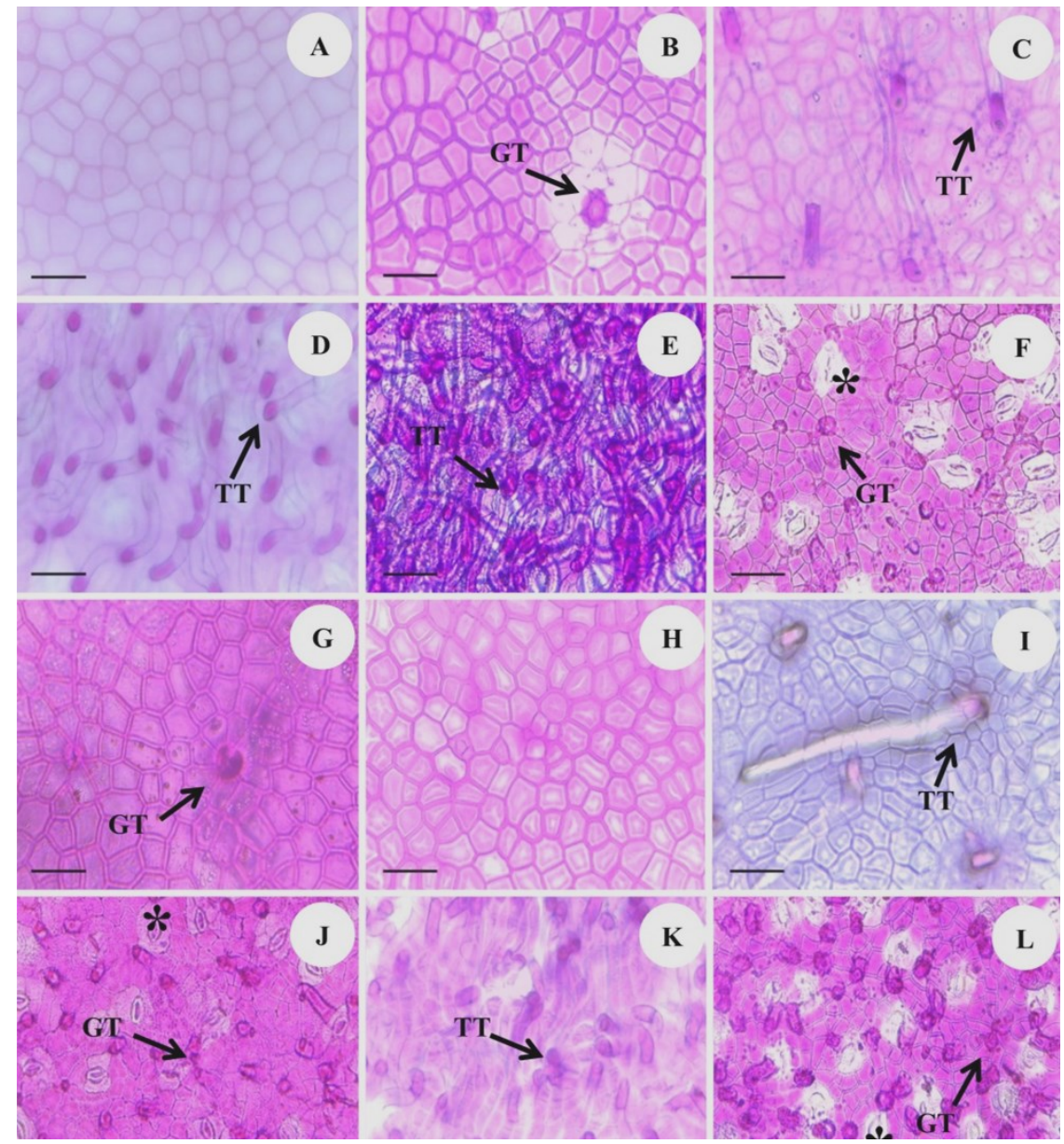

Figure 2. Frontal view of Senna cana's adaxial and abaxial epidermis at the three areas of analysis and under different light conditions. A-F. Leaves exposed to the Sun. G-L. Leaves in shadow. Images A, B, C, G, H, and I represent adaxial epidermis, while D, E, F, J, K, and L are the abaxial epidermis. Each column indicates a site analyzed in the study, which are the rocky outcrop (A), the sandy soil (B1) and the sandy soil with litter cover (B2), respectively. Note the difference in the distribution of stomata (circles) and trichomes (arrows). Asteristichs - stomata; GT - glandular trichome; TT - Tector Trichome. Scale bar: $50 \mu \mathrm{m}$. 
Transverse section of the leaves of $S$. canas howed that some characteristics are common to all the studied plants, such as the presence of a uniseriate epidermis covered by a cuticle on both faces, stomata positioned at the same level as the other epidermal cells, and the presence of a dorsiventral mesophyll (Figure 3). Additionally, this dorsiventral mesophyll presented a variation in the proportions of palisade and spongy parenchymas, which seems to be related to soil color and leaf sun exposure.
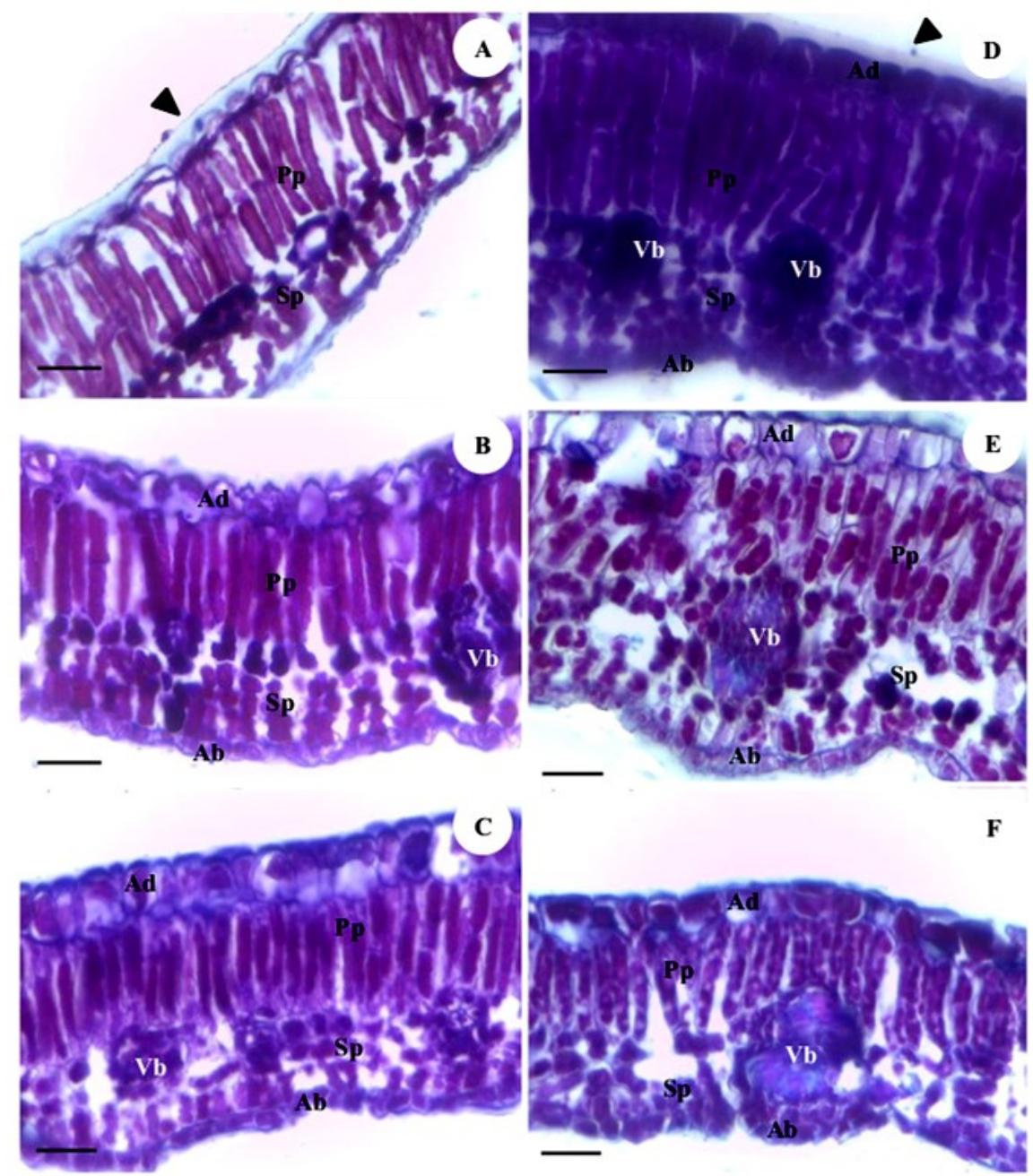

Figure 3. Transverse section of leaves of Senna canain rocky outcrops (A), sandy soil (B1) and sandy soil with litter (B2) under sunny and shady conditions. A-C. Leaves in full sun in areas A, B1, and B2, respectively. D-F. Leaves in the shade in areas A, B1, and B2. Observe the distribution of the different types of parenchyma in the mesophyll. Arrow - cuticle; Ad Adaxial epidermis; Ab - Abaxial epidermis; Vb - Vascular Bundle; Sp - Spongy parenchyma; Pp - Palisade parenchyma. Scale bar: $50 \mu \mathrm{m}$.

Table 1 summarizes the morphoanatomic data evaluated in the Senna cana leaves in different studyareas of the Caatinga that were analyzed.

Table 2 shows the quantitative data obtained through all the measurements. The species did not show a wide structural variation with location, but some parameters varied as described below.

Except for one individual from the area B2, all specimens presented glandular trichomes on the adaxial faces of the leaves, both in sunlight and shade (Figure 2). These did not differ significantly in density between the differentsites and the degree of exposure in which they were found, as observed by Gomes et al. (2009). These trichomes perform functions of high relevance to the plant because they store various substances, protect the plant against herbivoresand act as a barrier against atmospheric oxidative stress (LI et al., 2018). However, for Caatinga, the presence of tector trichomes is the mostcommon because it protects against the effects of high light intensity. 
Table 1. Morphonatomical characters observed in Senna cana leaves through histological analysis in different studiedarea of the Catimbau National Park, Buique-PE. A - Rocky outcrop, B1 - Sandy soil, B2 - Sandy soil covered by litter.

\begin{tabular}{|c|c|c|}
\hline TISSUE/REGION OF THE LEAF & ANALYZED CHARACTERS & CHARACTER TYPE \\
\hline 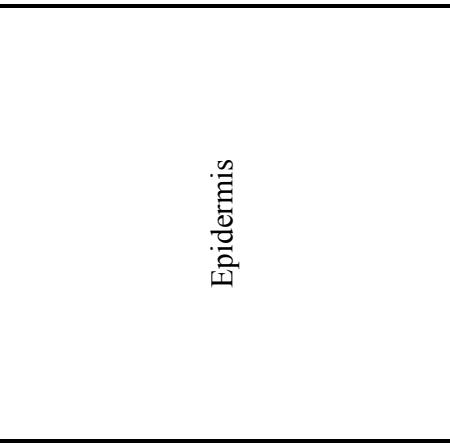 & $\begin{array}{c}\text { Number of cell layers } \\
\text { Sinuosity of the cell walls in the adaxial surface } \\
\text { Sinuosity of the cell walls in the abaxial surface } \\
\text { Presence of stomata on the epidermis } \\
\text { Stomata type } \\
\text { Arrangement of the stomata in frontal view } \\
\text { Position of the stomata in cross-section } \\
\text { Cuticle thickness } \\
\text { Presence of trichomes on the epidermis } \\
\text { Types of trichomes on the adaxial surface } \\
\text { Types of trichomes on the abaxial surface }\end{array}$ & $\begin{array}{c}\text { Uniseriate } \\
\text { Straight } \\
\text { Straight or sinuous } \\
\text { Amphystomatic } \\
\text { Paracytic } \\
\text { Aleatory } \\
\text { Same level of the other } \\
\text { epidermal cells } \\
\text { Thick } \\
\text { On both sides } \\
\text { Glandular } \\
\text { Tector or Glandular } \\
\end{array}$ \\
\hline \multirow[t]{2}{*}{ 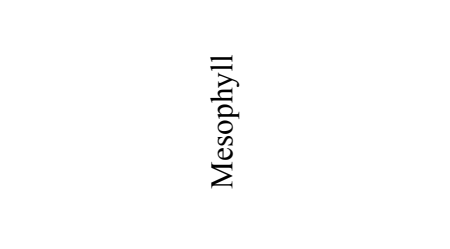 } & Number of layers of the palisade parenchyma & Dorsiventral \\
\hline & Number of layers of spongy parenchyma & $3-4$ \\
\hline
\end{tabular}

${ }^{1}$ Exception of an individual from area B2 (Sandy soil covered by litter).

Table 2. Quantitative data of leaves ofSenna cana sun and shade leaves in the study areas.A - Rocky outcrop, B1 - Sandy soil, B2 - Sandy soil covered by litter.

\begin{tabular}{|c|c|c|c|c|c|c|c|}
\hline \multirow{4}{*}{ 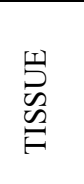 } & \multirow{4}{*}{$\begin{array}{l}\text { ANALYZED } \\
\text { CHARACTERS }\end{array}$} & \multicolumn{6}{|c|}{ STUDY AREAS } \\
\hline & & \multicolumn{2}{|c|}{$\mathrm{A}$} & \multicolumn{2}{|c|}{$\mathrm{B} 1$} & \multicolumn{2}{|c|}{ B2 } \\
\hline & & \multicolumn{6}{|c|}{ LIGHT CONDITION } \\
\hline & & SUN & SHADE & SUN & SHADE & SUN & SHADE \\
\hline \multirow{14}{*}{ 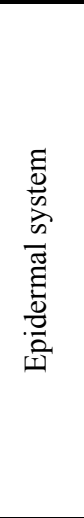 } & Thickness of adaxial & $14.94 \pm$ & $14.21 \pm$ & $18.09 \pm$ & $17.6 \pm$ & $15.21 \pm$ & $13.6 \pm$ \\
\hline & cuticle & $4.03^{\mathrm{ns}}$ & $1.78^{\mathrm{ns}}$ & $0.55^{\mathrm{ns}}$ & $0.96^{\mathrm{ns}}$ & $3.92^{\mathrm{ns}}$ & $4.92^{\mathrm{ns}}$ \\
\hline & Thickness of abaxial & $7.62 \pm$ & $8.61 \pm$ & $6.4 \pm$ & $8.5 \pm$ & $7.74 \pm$ & $7.29 \pm$ \\
\hline & cuticle & $1.87^{\mathrm{ns}}$ & $4.98^{\mathrm{ns}}$ & $1.27^{\mathrm{ns}}$ & $1.93^{\mathrm{ns}}$ & $1.43^{\mathrm{ns}}$ & $1.35^{\mathrm{ns}}$ \\
\hline & Thickness of adaxial & $3,81 \pm$ & $4.15 \pm$ & $4.99 \pm$ & $4.17 \pm$ & $3.89 \pm$ & $4.07 \pm$ \\
\hline & cell wall & $0.79^{\mathrm{ns}}$ & $1.17^{\mathrm{ns}}$ & $0.14^{\mathrm{ns}}$ & $1.13^{\mathrm{ns}}$ & $0.64^{\mathrm{ns}}$ & $0.91^{\mathrm{ns}}$ \\
\hline & Thickness of the & $18.59 \pm$ & $24.89 \pm$ & $19.2 \pm$ & $23.23 \pm$ & $24.35 \pm$ & $23.29 \pm$ \\
\hline & adaxial epidermis & $3.8^{\mathrm{ns}}$ & $3.9^{\mathrm{ns}}$ & $2.64^{\mathrm{ns}}$ & $5.97^{\mathrm{ns}}$ & $3.68^{\mathrm{ns}}$ & $3,43^{\mathrm{ns}}$ \\
\hline & Thickness of the & $11.11 \pm$ & $11.71 \pm$ & $13.38 \pm$ & $11.45 \pm$ & $13.52 \pm$ & $12.45 \pm$ \\
\hline & abaxial epidermis & $2.78^{\mathrm{ns}}$ & $0.69^{\mathrm{ns}}$ & $0.44^{\mathrm{ns}}$ & $1.53^{\mathrm{ns}}$ & $4.92^{\mathrm{ns}}$ & $3.47^{\mathrm{ns}}$ \\
\hline & Density of trichomes & $2,5 \pm$ & $1.26 \pm$ & $2.26 \pm$ & $1.66 \pm$ & $2.86 \pm$ & $2.36 \pm$ \\
\hline & on the adaxial surface & $0.36^{\mathrm{ns}}$ & $0.15^{\mathrm{ns}}$ & $0.05^{\mathrm{ns}}$ & $0.41^{\mathrm{ns}}$ & $1.3^{\mathrm{ns}}$ & $1.51^{\mathrm{ns}}$ \\
\hline & Density of trichomes & $58.9 \pm$ & $53.16 \pm$ & $80.43 \pm$ & $62.86 \pm$ & $44.1 \pm$ & $41.8 \pm$ \\
\hline & on the abaxial surface & $40.56^{\mathrm{ns}}$ & $6.09^{\mathrm{ns}}$ & $6.25^{\mathrm{ns}}$ & $0.41^{\mathrm{ns}}$ & $18.37^{\mathrm{ns}}$ & $12.73^{\mathrm{ns}}$ \\
\hline \multirow{6}{*}{ 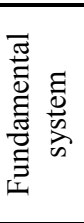 } & Palisade parenchyma & $106.56 \pm$ & $107.29 \pm$ & $111.72 \pm$ & $78.89 \pm$ & $88.78 \pm$ & $96.15 \pm$ \\
\hline & thickness & $32.92^{\mathrm{ns}}$ & $27.12^{\mathrm{ns}}$ & $16.92^{\mathrm{ns}}$ & $5.62^{\mathrm{ns}}$ & $11.24^{\mathrm{ns}}$ & $37.74^{\mathrm{ns}}$ \\
\hline & Spongy parenchyma & $48.19 \pm$ & $54.34 \pm$ & $65.14 \pm$ & $58.85 \pm$ & $61.45 \pm$ & $59.37 \pm$ \\
\hline & thickness & $4.29^{\mathrm{ns}}$ & $7.41^{\mathrm{ns}}$ & $24.27^{\mathrm{ns}}$ & $9.74^{\mathrm{ns}}$ & $6,83^{\mathrm{ns}}$ & $14.36^{\mathrm{ns}}$ \\
\hline & Mesophyll thickness & $154.35 \pm$ & $163.27 \pm$ & $174.77 \pm$ & $137.83 \pm$ & $149.97 \pm$ & $154.64 \pm$ \\
\hline & Mesopnyıl tnickness & $38.69^{\mathrm{ns}}$ & $29.27^{\mathrm{ns}}$ & $35.77^{\mathrm{ns}}$ & $18.82^{\mathrm{ns}}$ & $7.89^{\mathrm{ns}}$ & $52.67^{\mathrm{ns}}$ \\
\hline
\end{tabular}

${ }^{\mathrm{ns}}$ Not significant at $5 \%$ probability analysis of variance $(\mathrm{p}<0.05)$. 
The dense layer of tector trichomes is capable of filtering the direct radiation and reflecting it, thereby protecting the foliar tissues from radiation, and serving as mechanical protection against temperature and water loss (LOPRESTI, 2015). Although not common, the intense development of trichomes on the abaxial surface was reported by Rodrigues et al. (2009) in Senna alata (L.) Roxb., a common species in the Amazon. This feature may be characteristic of the Senna genus; however, this is yet to be validated. The soil coloration may have influenced the production and class of this anatomical attribute, since the areas with lightcolored soils (A and B1) exhibited tector-type trichomes, while the glandular trichomes dominated the plants on litter (B2) with the dark-colored substrate capable of absorbing light. Thus, the occurrence of tector trichomes in plants of the areas $\mathrm{A}$ and $\mathrm{B} 1$ can be related tot he photo-protective mechanism against radiation, reflected by soil covering, that can damage the photosynthetic system (NOVAIS et al., 2018).

The more significant cuticular development ameliorates transpiration and thus improves the plant's water-use efficiency (SANTOS et al., 2014), besides helping to protect against mechanical shocks. The species probably invest in high cuticle production on the adaxial surfaces because they are more exposed to sunlight than the lower surfaces, which are also protected by a higher density of trichomes. Both the cuticle and the hairs present on the abaxial surfaces defend the stomata against the stresses of solar radiation and temperature, which may explain the fact that they are located at the level of the other epidermal cells.

According to Fahn and Cutler (1992), the isobilateral mesophyll is a common characteristic of species from dry environments. Dickison (2000) mentioned that the tendency in such places is that the palisade parenchyma dominates, which is consistent with that observed for areas A and B1 (Figure 3). Furthermore, this mesophyll type seem to allow gas exchange during periods of low water availability, as well as the attenuation of the solar rays, which also affects these layers.

The presence of phenolic compounds in the studied specimens was verified (Figure 4, Table 3 ).
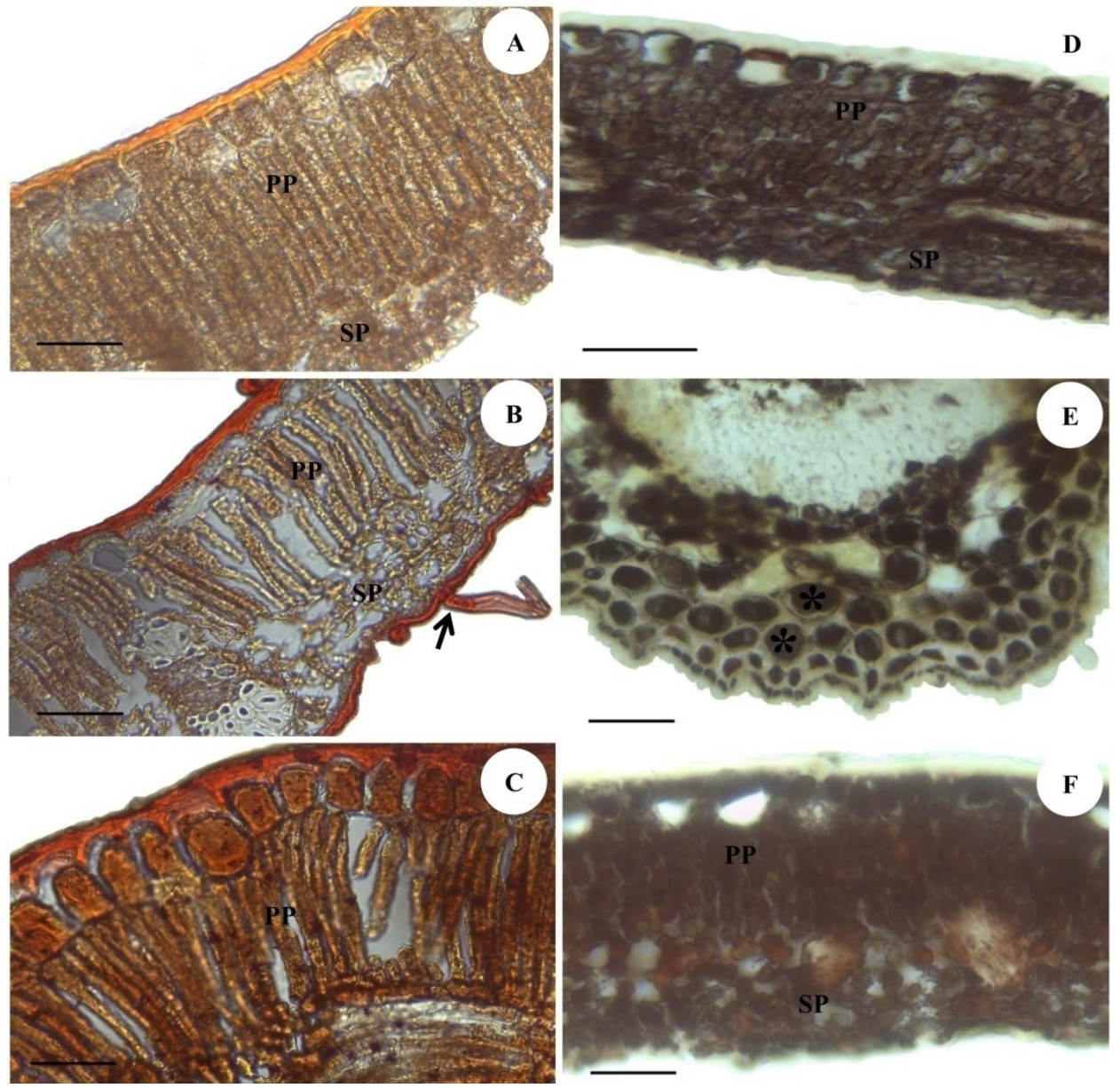

Figure 4. Presence of phenolic compounds and lipid substances in Senna cana leaves in the Catimbau National Park. A-C. Lipid substances present in leaves on rocky outcrops, sandy soil and litter sandy soil, respectively. D-F. Phenolic compounds (*) present in leaves on rocky outcrops, sandy soil and littered sandy soil. Observe lipids at the base of the trichomes (Arrow) and cells with phenolic content $(*)$. Sp - Spongy parenchyma; Pp - Palisade parenchyma. Scale bar: $50 \mu \mathrm{m}$.

Rev. Caatinga, Mossoró, v. 34, n. 1, p. 155 - 165, jan. - mar., 2021 
Table 3. Distribution of phenolic compounds and lipids in Senna cana leaves in different area of the Catimbau National Park, based on the presence $\left(+^{1},++^{2},+++^{3}\right)$ or absence (-) of these substances. A - Rocky outcrop, B1 - Sandy soil, B2 Sandy soil covered by litter.

\begin{tabular}{|c|c|c|c|c|}
\hline \multirow{2}{*}{ SUBSTANCE TYPE } & \multirow{2}{*}{ AREA } & \multirow{2}{*}{ REGION OF LEAF } & \multicolumn{2}{|c|}{ LIGHT CONDITION } \\
\hline & & & SUN & SHADE \\
\hline \multirow{9}{*}{ 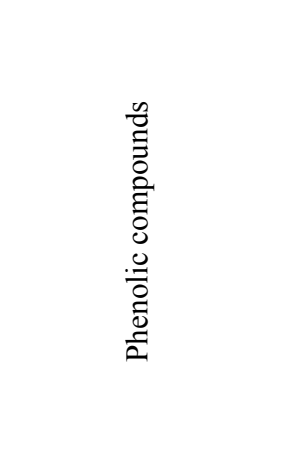 } & \multirow[t]{3}{*}{ A } & Cuticle & - & - \\
\hline & & Epidermis & $+{ }^{1}$ & $+++^{3}$ \\
\hline & & Mesophyll & $+{ }^{1}$ & $+++^{3}$ \\
\hline & \multirow[t]{3}{*}{ B1 } & Cuticle & - & - \\
\hline & & Epidermis & $++^{2}$ & $+++^{3}$ \\
\hline & & Mesophyll & $+++^{3}$ & $+++^{3}$ \\
\hline & \multirow[t]{3}{*}{ B2 } & Cuticle & - & - \\
\hline & & Epidermis & $+++^{3}$ & $+++^{3}$ \\
\hline & & Mesophyll & $+++^{3}$ & $+++^{3}$ \\
\hline \multirow{9}{*}{ 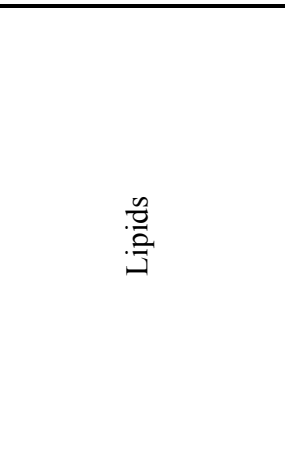 } & \multirow[t]{3}{*}{ A } & Cuticle & $+++^{3}$ & $+++^{3}$ \\
\hline & & Epidermis & $++^{2}$ & $+^{1}$ \\
\hline & & Mesophyll & $+{ }^{1}$ & $+{ }^{1}$ \\
\hline & \multirow[t]{3}{*}{ B1 } & Cuticle & $+++^{3}$ & $+++^{3}$ \\
\hline & & Epidermis & $+{ }^{1}$ & $+^{1}$ \\
\hline & & Mesophyll & $+{ }^{1}$ & $+^{1}$ \\
\hline & \multirow[t]{3}{*}{ B2 } & Cuticle & $++^{2}$ & $++^{2}$ \\
\hline & & Epidermis & $+{ }^{1}$ & $+^{1}$ \\
\hline & & Mesophyll & $+{ }^{1}$ & $+^{1}$ \\
\hline
\end{tabular}

$+=$ low amout of the compoud; $++=$ midle amount of the compound; $+++=$ high amount of the compound.

It is expected that such substances are commonly found in plants under high solar radiation due to the formation of specific components, such as flavonoids, which is accelerated by light (ZHAO et al., 2020). Phenolic compounds reduce light transmittance through the epidermal cells and protect photosynthetic tissues against excessive solar radiation (IZAGUIRRE et al., 2007). The variation in the presence of such substances in the leaves of Senna cana may be related to the type of soil in which the species was found, since a high concentration was observed in this study at the base of central leaf veins collected in areas A and B1 (Figure 4, Table 3). Both contain light-colored soil, which reflects the radiation directly incident to the abaxial faces of the leaves closest to the ground, generating luminous and thermal stress that induces the production of such substances as a protective mechanism. Silva et al. (2010) described the existence of more than 8,000 phenolic compounds in nature, that play roles that go beyond the inhibition of damage caused by ultraviolet rays, citing flavonoids as one of the main groups with antioxidant action in vegetables. Such characteristics added to herbivory protection (BARROS; SOARES, 2013) may explain the differentiated presence of these elements due to biotic and abiotic differences between environments.

Lipids were observed in the cuticles of all sampled leaves (Figure 4; Table 3). It is expected that they play a role in preventing moisture loss (CALVETE et al., 2002), and are well developed in xeric conditions, which coincides with the results obtained in the present study.

\section{CONCLUSIONS}

Senna cana presented morphoanatomic characters that, although presented little variation, were highly relevant for the permanence and distribution of the species in the Caatinga. These characters included thickened epidermal cell walls, uniseriate epidermis, stomata at the same level as the other epidermal cells, and thickened dorsiventral mesophyll. However, the presence of important plastic characteristics, comprising adaxial face trichome density, type of trichome, and dorsiventral mesophyll tissues, was highly evident when comparing the three areas studied and the level of insolation incident on the leaves of the species.

The solar radiation and location of the individuals were shown to be conditions that promoted specific anatomical modifications, 
revealing a high adaptive capacity of the species under Caatinga conditions. Additionally, the radiation reflected by different soil coverings was likely responsible for promoting morphological, anatomical, and histopathological changes in $S$. cana leaves, especially those closer to the soil. Specimens located in light-colored soils developed more significant protective characteristics for radiation, which suggests that indirect light action causes anatomical changes in plants and must be taken into consideration in future studies seeking to investigate anatomical variations related to luminosity.

\section{ACKNOWLEDGMENTS}

The authors thank to Laboratório de Anatomia e Bioquímica de Plantas of Universidade Federal Rural de Pernambuco for technical support. We also thank Lucas Costa and José Nailson for statistical support, organization and discussed the data.

\section{REFERENCES}

ALCOFORADO-FILHO, F. G. et al. Florística e fitossociologia de um remanescente de vegetação caducifólia espinhosa arbórea em Caruaru, Pernambuco. Acta Botanica Brasílica, 17: 287-303, 2003.

ARAÚJO, F. S. et al. Floristics and life-forms along a topographic gradient, central-western Ceará, Brazil. Rodriguésia, 62: 341-366, 2011.

ARAÚJO FILHO, J. C. et al. Solos da Caatinga. In: CURI, N. et al. (Eds.). Pedologia: solos dos biomas brasileiros. Viçosa, MG: Sociedade Brasileira de Ciência do Solo, 2017. cap. 5, p. 227-260.

ASHRAF, M. A. et al. Environmental stress and secondary metabolites in plants: an overview. In: AHMAD, P. et al. (Eds.) Plant metabolites and regulation under environmental stress. London, UK: Academic Press, 2018. p. 153-167.

BARROS, I. O.; SOARES, A. A. Adaptações anatômicas em folhas de marmeleiro e velame da caatinga brasileira. Revista Ciência Agronômica, 44: 192-198, 2013.

BOEGER, M. R. T.; GLUZEZAK, R. M. Adaptações estruturais de sete espécies de plantas para as condições ambientais da área de dunas de Santa Catarina, Brasil. Iheringia. Série Botânica, 61: 73-82, 2006.

CALVETE, E. O. et al. Análises anatômicas e da biomassa em plantas de morangueiro cultiva-das in vitro e ex vitro. Horticultura Brasileira, 20: 649$653,2002$.

COSTA, G. M. et al. Variações locais na riqueza florística em duas ecorregiões de caatinga. Rodriguésia, 66: 685-709, 2015.

DICKISON, W.C. Integrative plant anatomy. New York: Academic Press, 2000. 533 p.

FAHN, A.; CUTLER, D. I. Xerophytes. Berlin: Gebrüder Broentaeger, 1992. 176 p.

FAN, X-X. et al. Effects of light intensity on the growth and leaf development of young tomato plants grown under a combination of red and blue light. Scientia Horticulturae, 153: 50-55, 2013.

FIGUEIREDO, K. V. et al. Changes in leaf epicuticular wax, gas exchange and biochemistry metabolism between Jatropha mollissima and Jatropha curcas under semi-arid conditions. Acta Physiologiae Plantarum, 37: 1-11, 2015.

GERLACH, D. Botanische Mikrotechnik. Stuttgart: Georg Thieme Verlag, 1984. p. 311 p.

GOMES, P. A. et al. Influência do sombreamento na produção de biomassa, óleo essencial e quantidade de tricomas glandulares em cidrão (Lippia citriodora Lam.). Biotemas, 22: 9-14, 2009.

GOMES, P.; ALVES, M. Floristic diversity of two crystalline rocky outcrops in the Brazilian northeast semi-arid region. Brazilian Journal of Botany, 33: 661-676, 2010.

GUERFEL, M. et al. Impacts of water stress on gas exchange, water relations, chlorophyll content and leaf structure in the two main Tunisian olive (Olea europaea L.) cultivars. Scientia Horticulturae, 119: 257-263, 2009

GUERRA, A.; SCREMIN-DIAS, E. Leaf traits, sclerophylly and growth habits in plant species of a semiarid environment. Brazilian Journal of Botany, 41: 131-144, 2018.

INSTITUTO BRASILEIRO DE GEOGRAFIA E ESTATÍSTICA - IBGE. Mapa de biomas do Brasil, primeira aproximação. Rio de Janeiro: 2004

IZAGUIRRE, M. M. et al. Solar ultraviolet-B radiation and insect herbivory trigger partially overlapping phenolic responses in Nicotiana attenuata and Nicotiana longiflora. Annals of Botany, 99: 103-109, 2007. 
JOHANSEN, D. A. Plant Microtechnique. New York: McGraw-Hill Book Co., Inc., 1940. 523 p.

KARABOURNIOTIS, G. et al. Protective and defensive roles of non $\square$ glandular trichomes against multiple stresses: structure-function coordinat. Journal of Forestry Research, 31: 1-12, 2020.

KIM, G. T. et al. Photomorphogenesis of leaves: shade-avoidance and differentiation of sun and shade leaves. Photochemical \& Photobiological Sciences, 4: 770-774, 2005.

KRAUS, J. E.; ARDUIN, M. Manual básico de métodos em morfologia vegetal. Rio de Janeiro: EDUR, 1997. 198 p.

LEITE, A. M.; LLERAS, E. Ecofisiologia de plantas da Amazônia. I Anatomia foliar e ecofisiologia de Pogonophora schomburgkiana Miers. (Euphorbiaceae). Acta Amazonica, 8: 365-370, 1978.

LI, S. et al. Glandular trichomes as a barrier against atmospheric oxidative stress: relationships with ozone uptake, leaf damage, and emission of LOX products across a diverse set of species. Plant, Cell \& Environment, 41: 1263-1277, 2018.

LIMA, A. L. A. et al. Do the phenology and functional stem attributes of woody species allow for the identification of functional groups in the semiarid region of Brazil? Trees, 26: 1605-1616, 2012.

LOPES-SILVA, R. F. et al. Composição florística de um inselberg no semiárido paraibano, nordeste brasileiro. Rodriguésia, 70: 1-14, 2019.

LOPRESTI, E. F. Chemicals on plant surfaces as a heretofore unrecognized, but ecologically informative, class for investigations into plant defence. Biological Review, 91: 1102-1117, 2015.

MACHADO, W. J. et al. Floristic composition in areas of Caatinga and Brejo de Altitude in Sergipe state, Brazil. Check List, 8: 1089-1101, 2012.

MONTEIRO, J. A. Estudo químico e farmacológico de Senna cana H.S. Irwin \& Barneby. 2012. 106 f. Dissertação (Mestrado em Química Orgânica) - Universidade Federal do Ceará, Fortaleza, 2012.

NOVAIS, J. W. Z. et al. Variação espaço-temporal da par refletida pelo solo e transmitida pelo dossel em floresta inundável no pantanal matogrossense.Ciência Florestal, 28: 1502-1513, 2018.

PARISI, A. V. et al. A study of the total ultraviolet exposure 19 to all the leaves for small plant growth.
Journal of Photochemistry and Photobiology B: Biology, 45: 36-42, 1998.

PRADO, D. As Caatingas da América do Sul. In: LEAL, I. R. et al. (Eds). Ecologia e conservação da Caatinga: uma introdução ao desafio. Recife, PE: Editora Universitária da UFPE, 2003. v. 1, p. 3-73.

PURVIS, M. J. et al. Laboratory techniques in botany. Washington, D.C.: Butterworth, 1964. 317 p.

QUESADA, M. et al. Succession and management of tropical dry forests in the Americas: review and new perspectives. For Ecol Manag, 258: 1014 $1024,2009$.

ROCHA, P. L. B. et al. Plant species and habitat structure in a sand dune field in the Brazilian Caatinga: a homogeneous habitat harbouring an endemic biota. Brazilian Journal of Botany, 27: 739-755, 2004

RODAL, M. J. N. et al. Levantamento quantitativo das plantas lenhosas em trechos de vegetação de caatinga em Pernambuco. Revista Caatinga, 21: 192 $-205,2008$

RODRIGUES, I. M. C. et al. C. Anatomy and histochemistry of Senna alata leaves. Planta Daninha, 27: 515-526, 2009.

SANTANA, J. A. S. et al. Estrutura e distribuição espacial da vegetação da Caatinga na Estação Ecológica do Seridó, RN. Pesquisa Florestal Brasileira, 36: 355-361, 2016.

SANTOS, H. G. et al. Sistema brasileiro de classificação de solos. 3. ed. Brasília, DF: Embrapa, $2013.353 \mathrm{p}$.

SANTOS, P. S., et al. Diferenças sazonais no aporte de serrapilheira em uma área de caatinga em Pernambuco. Revista Caatinga, 24: 94-101, 2011.

SANTOS, M. G. et al. Caatinga, the Brazilian dry tropical forest: can it tolerate climate changes? Theoretical and Experimental Plant Physiology, 26: 83-99, 2014.

SASS, J. E. Botanical microtechnique. Ames, Iowa: Iowa State College Press, 1951. 228 p.

SCHLICHTING, C. D. Phenotypic plasticity in plants. Plant Species Biology, 17: 85-88, 2002.

SILVA, M. C. L. et al. Compostos fenólicos, carotenóides e atividade antioxidante em produtos vegetais. Semina: Ciências Agrárias, 31: 669-682, 2010 . 
YANG, J. et al. Induced accumulation of cuticular waxes enhances drought tolerance in Arabidopsis by changes in development of stomata. Plant Physiology and Biochemistry, 49: 1448-1455, 2011.

YOO, C. Y. et al. The Arabidopsis GTL1 transcription factor regulates water use efficiency and drought tolerance by modulating stomatal density via transrepression of SDD1. Plant Cell, 22: 4128-4141, 2010.

ZHAO, B. et al. UV-B promotes flavonoid synthesis in Ginkgo biloba leaves. Industrial Crops and Products, 151: 112483, 2020. 